\title{
APPLICATION OF SOUND TOMOGRAPHY IN THE REVITALIZATION OF THE AREA SURROUNDING THE NATIVITY OF THE BLESSED VIRGIN MARY ORTHODOX CHURCH IN WKODAWA
}

\author{
Margot Dudkiewicz
}

\section{Summary}

The main purpose of the present work was to examine the effectiveness of using information technology tools in the form of ultrasound computed tomography in the reclamation of historical garden space. The obtained dendrological inventory results were applied in carrying out a project of revitalizing the area around the historic orthodox church in Włodawa. The city is located in the central-eastern part of Poland, near the border with Belarus and Ukraine. The origins of the orthodox parish date back to the turn of the fifteenth and sixteenth centuries. The orthodox church was erected in the Byzantine-Classicist style, on the Greek cross plan with three apses from the altar side. In 2017, the renovation of the temple building and its surroundings began at the initiative of the Lublin-based Dialog Foundation. During the dendrological stocktaking process of the area around the church, the studies conducted with the help of specialized diagnostic equipment in the form of Picus 3 Sonic Tomograph were particularly important. The tests will allow for early diagnosis and selection of the best course of action in view to increasing the safety of users and preserving the historic substance of the site. Within the area of the estate there are 20 trees growing, differing in their age and health condition, with a quantitative advantage of common chestnut trees, planted without proper compositional arrangement or sacred symbolic. The management plan of the tree envisages the removal of 8 trees for sanitary reasons, whereas the corrective and sanitary cutting of branches should be applied to all the other trees. On the basis of the collected material, the options and possible directions for the improvement of the orthodox church's surroundings were presented.

\section{Keywords}

ultrasound computed tomography • Picus Sonic Tomograph 3 • Włodawa • orthodox church

\section{Introduction}

Włodawa is located in the eastern part of the Lublin province, near the border with Ukraine and Belarus. The city is surrounded by picturesque geographical regions the Polesie Lubelskie, and the Pojezierze Łęczyńsko-Włodawskie (lake district) as well as protected areas - Polesie National Park, Polesie Landscape Reserve, and Sobibór 
Landscape Reserve. The natural values of the Lublin Region distinguish this area on the scale of Poland and Europe. The attractiveness of the Włodawa district is also derived from its well-preserved historical monuments, related to the centuries-old tradition, which testify to the cultural and ethnic diversity of the region. The Orthodox Church of the Nativity of the Most Holy Mother of God is counted among the most important architectural objects. The building represents the Byzantine-Russian style with classicist elements. The church is located at number 11 in Kościelna street, on the embankment by the Bug River (Fig. 1). The area surrounding the building, overgrown with trees, originally served as the parish cemetery. In 2017, on the initiative of the Dialog Foundation in Lublin, a general renovation of the temple building was initiated, financed from the Regional Operational Program of the Lublin Region. The surroundings of the church also require improvement works, preceded by in-depth interdisciplinary research. The paper presents the process of dendroflora valorisation around the historic facility, using computer technologies.



Source: developed by the author

Fig. 1. Location of the orthodox church in Włodawa

The safety of persons and property in the area where the historic tree stand is growing is of utmost importance, and it requires the use of precise techniques to detect tree decay and other types of structural defects inside tree trunks. From the point of view of the protection, conservation and care of trees, the most appropriate methods for diagnosing the health of trees are those that least interfere with their tissue. The potential risk of overturning of the aged tree depends not only on the diagnosed trunk defect but also on the species, on the general health of the tree, and on the influence of external factors. Tree decay often, for a long time, fails to produce visible symptoms on the outside, and therefore, for the proper recognition of the presence of decomposition inside the trunk, it is necessary to use more precise tools in order to accurately analyse 
the internal structure of the tree trunk [Hayes 2001, Pokorny 2003, Luley 2005, Wang and Allison 2008]. For this purpose, the computed tomography and the non-invasive Picus 3 device are used. The presence of the decay and its degree of advancement will indicate the poor condition of the tree, and then, for example, under the influence of wind, the weight and movement of the crown may cause the limb of the tree trunk or tree root system to break, resulting in the tree breaking or falling. Trees classified as potentially endangering safety are marked for observation, or intended for maintenance treatments conducted in order to correct their statics. Correction of the tree's silhouette is obtained by skilful cutting, which reduces the mass of the crown, or by fitting mechanical reinforcements and supports, which - albeit they not removing the cause of danger - may for some time safeguard the tree from falling. The frequency of use of the place in the vicinity of the tree is also important, as well as the presence of potential objects that are located within the range of destruction potentially caused by the tree falling, and thus may be damaged.

The main purpose of the work was to examine the effectiveness of the use of computer tools in the restoration of garden space. The results obtained were used in order to implement the tree stand management plan. The historical iconographic and cartographic materials, as well as written sources, were also used in the process of developing the improvement project. The research was carried out in the period of 2016-2017.

\section{Material and methods}

During the field studies, the actual condition of 20 trees was examined, and dendrological description thereof has been developed. Their basic dendrometric measurements were taken (including: trunk circumference, crown range and tree height) and the health condition of the trees was described in detail. Species were determined based on professional dendrological literature [Seneta and Dolatowski 2012]. The trunk circumferences were measured at a height of $130 \mathrm{~cm}$ above the ground surface, using measuring tape with the accuracy down to one centimetre. The crown projection diameter was measured using a Leica DISTO D5 laser range finder.

The ultrasound computed tomography enables non-invasive measurement of the health condition of the trunk interior in terms of detecting rot, hollows or projections using sound waves, without requiring invasive boreholes [Göcke et al. 2007, Brazee et al. 2011]. The measuring apparatus for tomographic examinations includes: a central unit (Photo 1), sensors placed around the trunk of a tree in an amount depending on its circumference (Photo 2), connected to the pins driven shallow into the trunk, as well as specialized software. Sensors measure the time of sound wave propagation in the wood of the tree, caused by the impact of an electronic hammer. The distances between the sensors are measured using a special PiCUS Calliper, working in the Bluetooth system. The outcome of processing the results by the software is a colourful tomogram, on which changes taking place inside the trunk of the tree are visible.

When analysing the results obtained using the ultrasound computed tomography, it is necessary to pay attention to the colour scheme of the image, which determines the 
so-called wood density map. Individual colours mean different velocities of the sound projection within the trunk, depending on the elasticity and density of the wood. Colour from light brown to black corresponds to a range of 60 to $100 \%$ of the highest velocity of sound projection, which means live and healthy tissue. Different shades of green colour correspond to 40 to $60 \%$ of the velocity of sound projection on an average level, which is synonymous with a slight deterioration in the structure of the wood. Pink colour means sound projection in the range between 20 and $40 \%$, whereas the colour from blue to white signifies sound projection velocity in the range of $0-20 \%$ (the slowest velocity of sound projection) - these are therefore the areas with the weakest structure, where damage and intense wood decay has already occurred [Chomicz 2007, Chomicz 2010]. The yellow lines on the trunk cross-section suggest the occurrence of internal cracks, extremely dangerous due to the fact that there are no obvious external symptoms that could confirm this. The thicker the line, the greater the risk of such an occurrence. In turn, the red line on the tomogram means the threshold thickness of the wall, which facilitates the determination of the minimum mechanical strength of the tree trunk. Such data is helpful in calculating the so-called $t / R$ coefficient, that is the ratio of healthy wood ( $\mathrm{t}$ ) to the radius of the tree trunk (R), which should not be lower than 0.33; and in the case of trees with closed cavities, even 0.3 [Hayes 2002, Kane et al. 2001, Mattheck et al. 2015, Suchocka 2012, Durlak et al. 2017a, Durlak et al. 2017b].

The age of trees is an estimate, and therefore one should not be persuaded by excessive disparities. The latter can be influenced by many factors (environmental conditions, soil fertility, soil moisture, growth rate or genetic factors), therefore plantings from the same period may vary considerably in their age scale [Szczepanowska et al. 2010, Mydłowska 2014].

On the basis of dendrological inventory coupled with the analysis of historical materials, the concept for the improvement of the temple's surroundings was created.

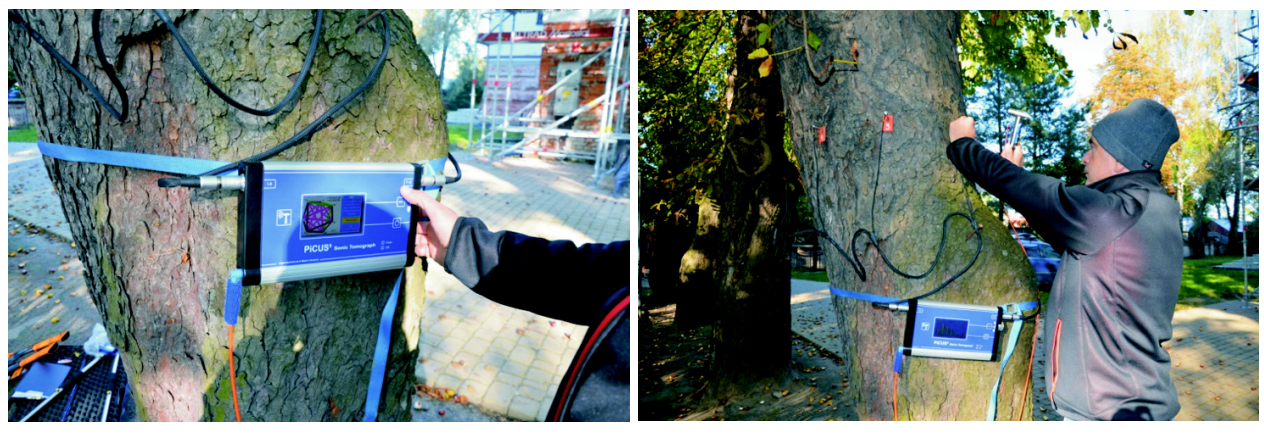

Photo 1. Central unit of the Picus 3 ultrasound computed tomography device (photo by M. Dudkiewicz, 2017)

Photo 2. Process of examining health status of a tree using the Picus 3 ultrasound computed tomography device (photo by M. Dudkiewicz, 2017) 


\section{Results}

\subsection{Outline of the object's history}

The history of Włodawa dates back to the Slavic times of the Cherven Cities, the thirteen-century Tatar invasions, and Prince Daniel. In the mid-fifteenth century, the present Polesie Lubelskie and Pojezierze Łęczyńsko-Włodawskie Lakeland constituted the borderland between the Kingdom of Poland and the Grand Duchy of Lithuania.

The origins of the orthodox parish in Włodawa go back to the turn of the fifteenth and sixteenth centuries, and they are associated with the persons of the Olgierdowicz and Sanguszko princes, the starost of Vladimir, prince Teodor Andreyewich, and then priest Alexander Pronsky. The first written mention of the Orthodox church dedicated to the Nativity of the Holy Virgin dates to 1564.

The construction of the existing orthodox church in Włodawa, after dismantling the former, decayed wooden one, was undertaken in 1893 by a construction entrepreneur Piotr Ksenek from Siedlce, according to the design by Viktor Ivanovych Sychugov, member of the Imperial Academy of Fine Arts in St. Petersburg. The church received the names of: Saint Alexander Nevsky, the Birth of the Holy Mother of God, and Saint Nicholas the Miracle-Worker. The church was consecrated by Bishop Gedeon of Lublin in 1895. Towards the end of the nineteenth century, at the Włodawa church, there were two belfries, each with five bells in it. The first parsonage was built in 1813, and the present one dates to the turn of the nineteenth and twentieth centuries and has undergone a complete renovation since [Pelica 2015].

The Włodawa orthodox church is built of brick, and it represents a mixed Byzantine-Russian and classicist style. The building is oriented towards the East, constructed on the plan of a Greek cross, with three apses from the east (Photo 3). The façade is crowned with three towers - the highest one in the middle, and two smaller ones to the sides. Orthodox crosses were placed on the domes of all the towers, whereas the tops of the transept and presbytery chapels are crowned with Latin crosses (Photo 4). The windows of the building are enclosed with semi-circular arches, decorated with archivolts bearing serrated ornament. The building has a high, rusticated plinth and a round cornice with a decorative frieze around it. The entrance to the temple leads through three portals: the west (main) portal, the north portal, and the south portal, each placed in an avant-corps. The tri-partite building is covered with a barrel vault. Inside, among other things, we find an iconostasis from 1843, designed by Andrzej Cieszyński, consisting of several dozen of icons. The church also holds an icon of John Chrysostom from the turn of the seventeenth and eighteenth centuries, and a Baroque altar cross from the turn of the eighteenth and nineteenth centuries [Superczyńska 2002].

The orthodox church and presbytery are entered in the register of monuments under the entry number A/234. 


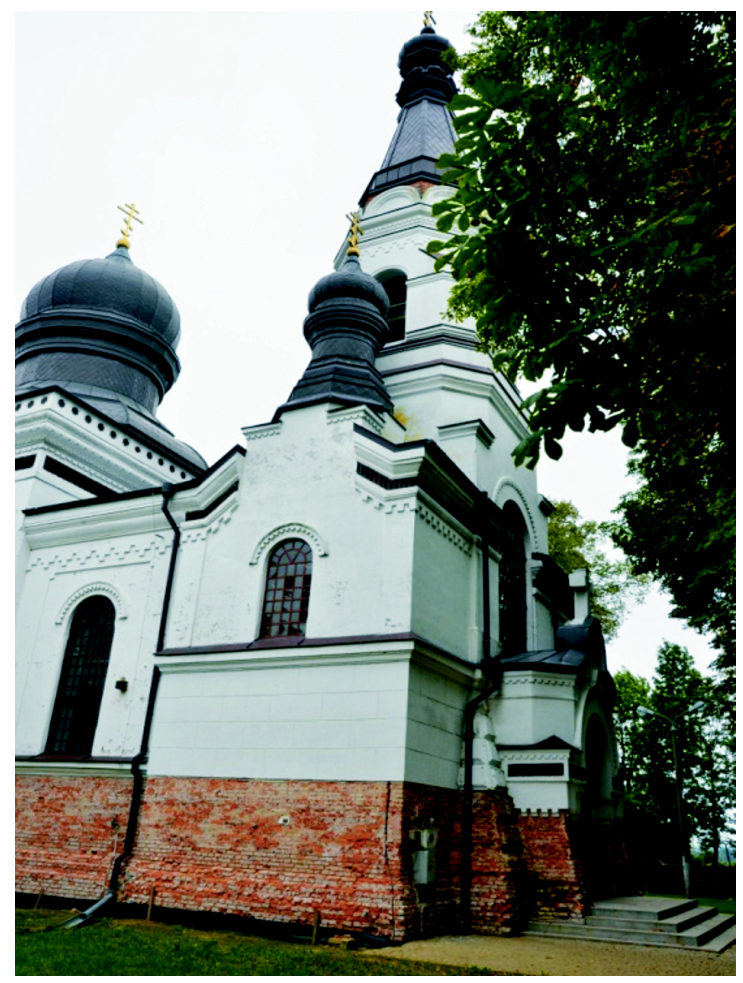

Photo 3. Entrance to the orthodox church from the east (photo by M. Dudkiewicz, 2017)

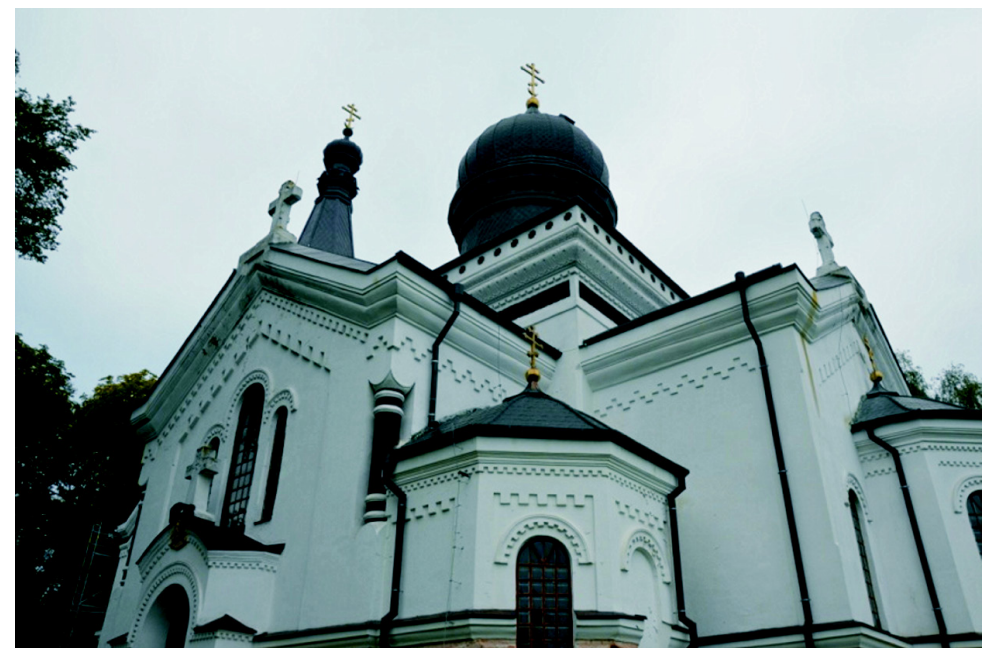

Photo 4. Details of the architecture - tower domes with Orthodox and Latin crosses, and the cornice with a decorative frieze (photo by M. Dudkiewicz, 2017) 


\subsection{Stock-taking of the orthodox church's surroundings}

Within the area of the surrounding estate there are 20 trees growing, varying in age and in health status, with a quantitative advantage of horse-chestnut trees (Photos 5 and 6). Some trees have been self-sown, and some have been planted without adherence to the proper compositional layout or sacred symbolism. Around the temple there is a churchyard cemetery with four tombstones (Photos 7 and 8). The compound is enclosed with a fence, which is partly in the form of an old brick wall (Photos 9 and 10), and partly in the form of brick posts and metal spans.
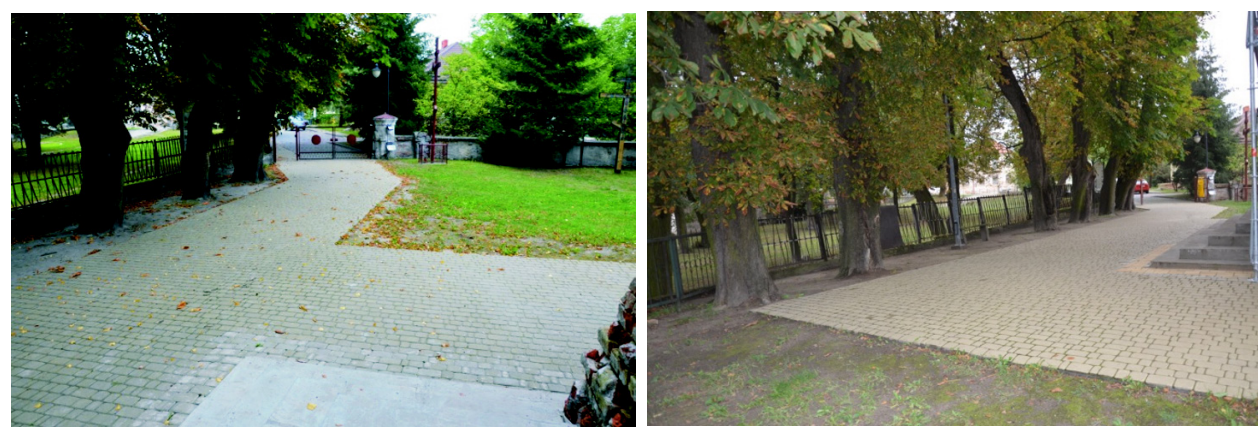

Photos 5 and 6. The courtyard and the lane outside the entrance to the orthodox church (photos by M. Dudkiewicz, 2017)


Photos 7 and 8. Surroundings of the orthodox church. Burial ground around the church (photos by M. Dudkiewicz, 2017)

A total of 20 trees were inventoried on the site, of which the following are dominant: horse-chestnut (Aesculus hippocastanum L.), Norway spruce (Picea abies (L.) H. Karst) and common pine (Pinus sylvestris L.) (Table 1). In addition to the above we also find: silver birch (Betula pendula Roth.) and small-leaved lime (Tilia cordata Mill.). 

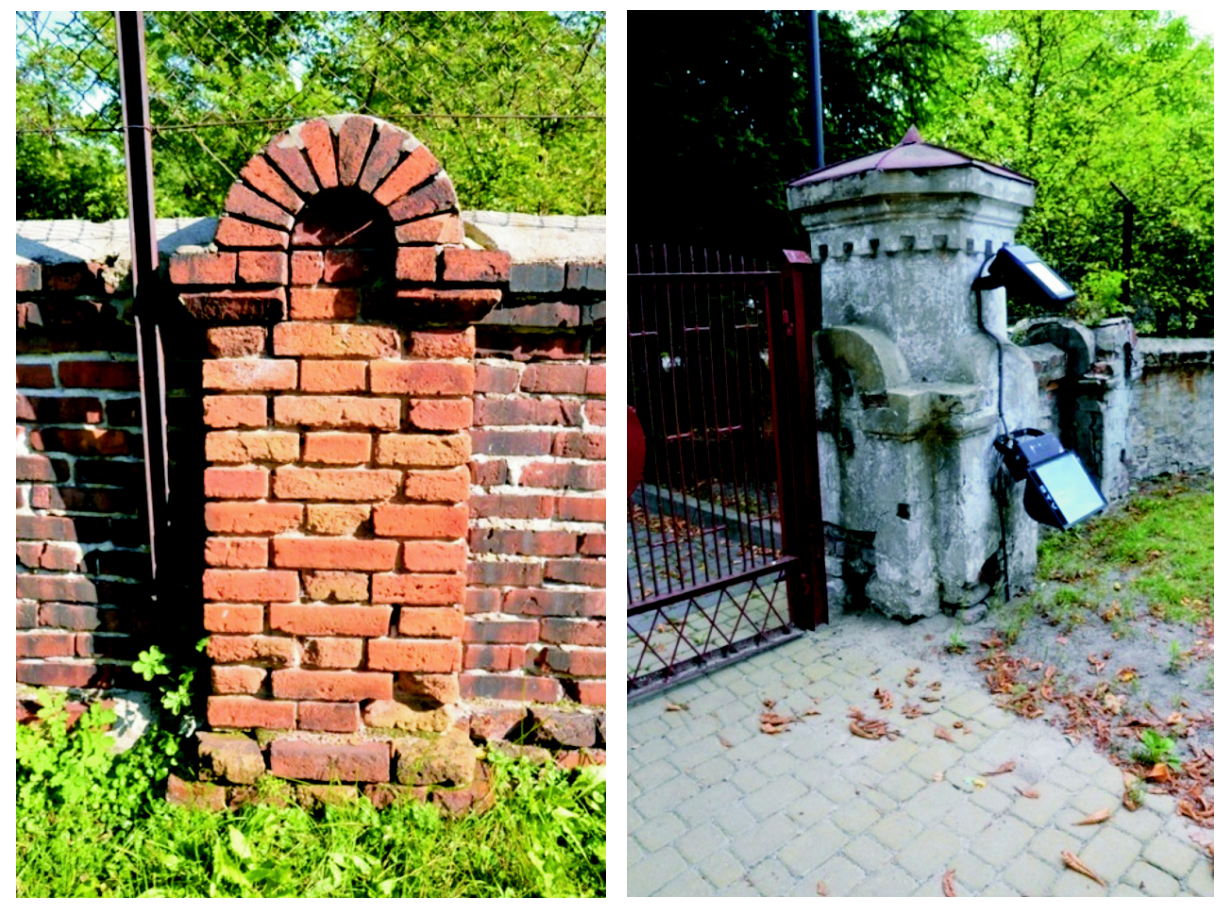

Photos 9 and 10. The oldest fragments of the former fence (photos by M. Dudkiewicz, 2017)

Table 1. Species composition and quantities of tress around the orthodox church in Włodawa

\begin{tabular}{|c|c|c|c|c|}
\hline No. & Latin name & English name & Quantity & $\begin{array}{c}\text { Trunk } \\
\text { circumference }\end{array}$ \\
\hline 1. & Aesculus hippocastanum L. & Horse-chestnut (conker tree) & 10 & from 210 to $300 \mathrm{~cm}$ \\
\hline 2. & Betula pendula Roth & $\begin{array}{c}\text { Silver birch (European white } \\
\text { birch) }\end{array}$ & 2 & from 157 to $232 \mathrm{~cm}$ \\
\hline 3. & Picea abies (L.) H. Karst & Norway spruce & 4 & from 44 to $62 \mathrm{~cm}$ \\
\hline 4. & Pinus sylvestris L. & Scots pine & 3 & from 66 to $81 \mathrm{~cm}$ \\
\hline 5. & Tilia cordata Mill. & Small-leaved lime (linden) & 1 & $330 \mathrm{~cm}$ \\
\hline
\end{tabular}

Source: developed by the author

The management plan of the tree stand envisages the removal of 8 trees, mainly horse-chestnuts, for sanitary reasons. Corrective and sanitary cutting of branches should cover all the other trees. For one specimen, the use of elastic bonds is suggested. The following are the results of a detailed inventory, as well as tomograms of specimens with the largest lesions (Table 2, Figures 2, 3, 4, and 5). 


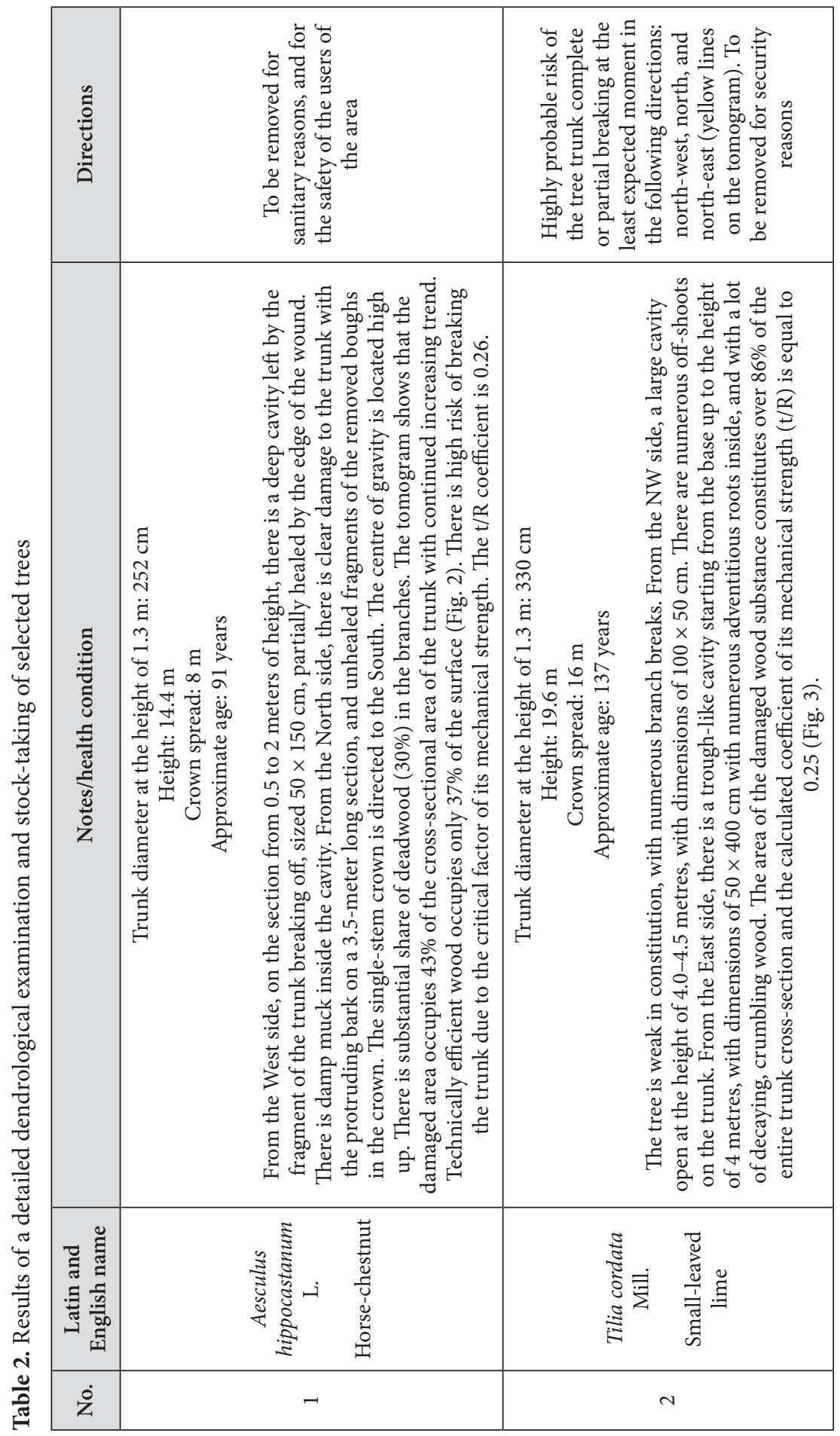




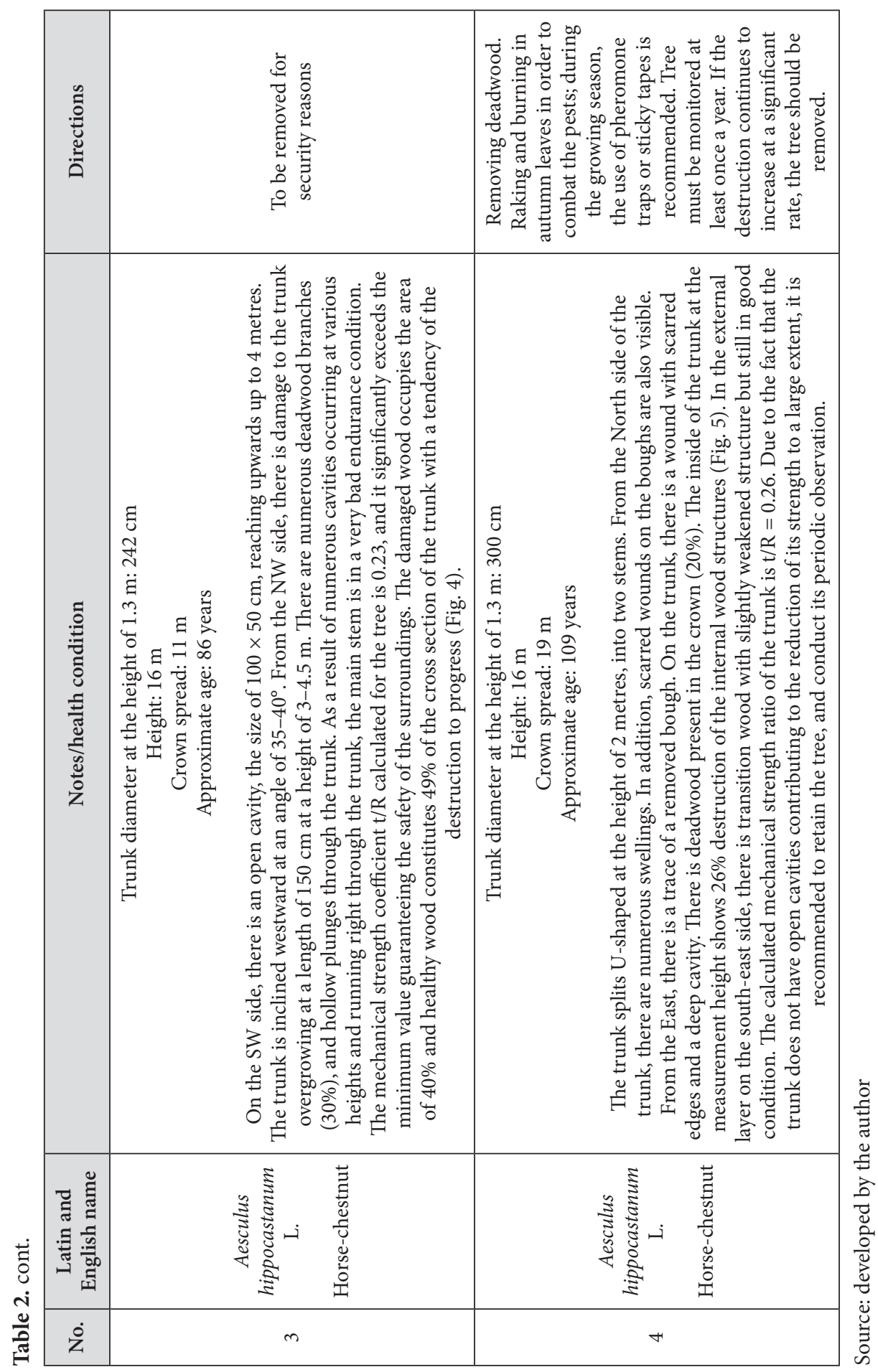




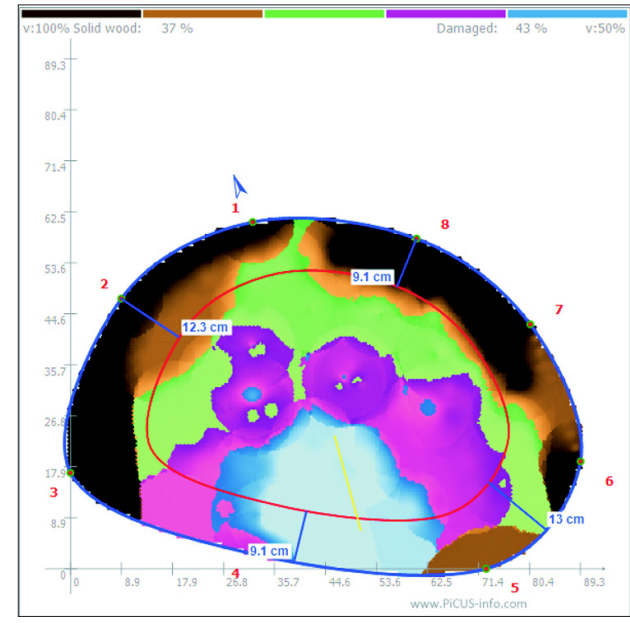

Source: developed by the author, 2017

Fig. 2. Tomogram of the Aesculus hippocastanum horse chestnut tree No. 1

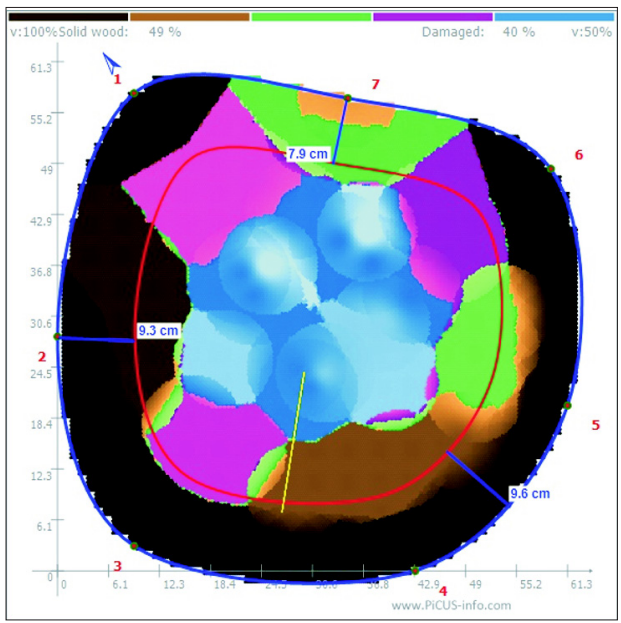

Source: developed by the author, 2017

Fig. 4. Tomogram of the Aesculus hippocastanum horse chestnut tree No. 3

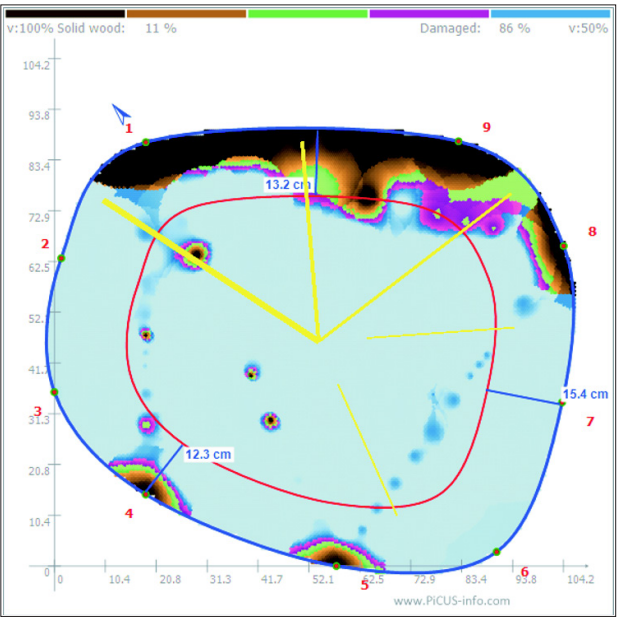

Source: developed by the author, 2017

Fig. 3. Tomogram of the Tilia cordata lime tree No. 2

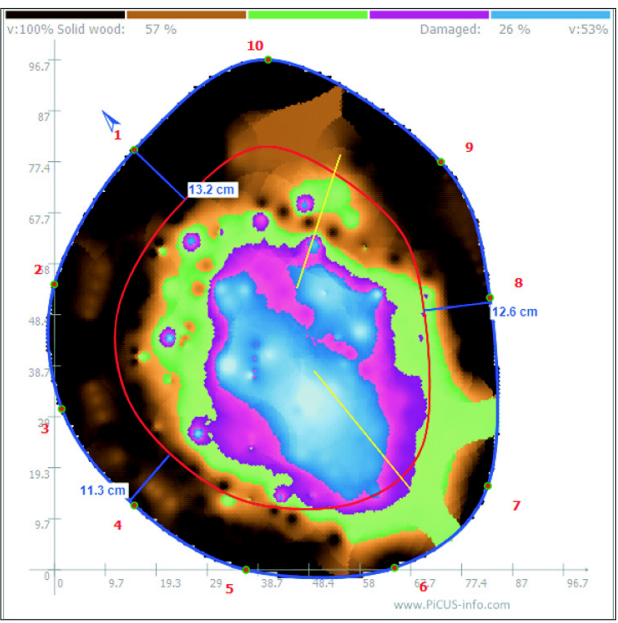

Source: developed by the author, 2017

Fig. 5. Tomogram of the Aesculus hippocastanum horse chestnut tree No. 4

\section{Concept plan for improvements}

In the case of restoration of the greenery layout within the compound of any historic sacral building, the basic principle of the study should be to refer to the historical selec- 
tion of species in such facilities, and planting according to the rules of religious symbolism [Misiak 2010, Szcześniak 2014, Gray 2015, Kujawska and Łuczaj 2016].

In the past, the main principle in erecting churches was locating them in places marked by: a miracle, a revelation, or ardent faith of the faithful. Furthermore, in their very composition, sacred buildings were also harmoniously integrated into nature. Currently, the surroundings of the old orthodox churches often remain the last refuge for ancient, tall trees. Among numerous, contemporary transformations of the rural landscape, old temples surrounded by greenery remind us of human striving for harmony with the world. The arrangement of the orthodox church's surroundings mainly includes the following colours: green, white and brown. Green is the colour of spring and of rebirth. In sacred iconography, green is the herald of the Holy Spirit as well as the colour of John the Evangelist and many prophets. The white colour in the symbolism of the Orthodox church symbolizes God's revelation and glory. White is an expression of joy and of festive mood, while it also symbolizes purity, innocence, God's wisdom, joy and happiness. The brown colour symbolizes the material world, as well as humility and poverty [Uścinowicz 1997, Keczyńscy 1999, Kępkowicz and Gawryluk 2009].

The projected plan involves the introduction of new trees, in addition to planting of shrubs and perennials that will increase the attractiveness of the compound, as well as highlighting its sacred character. An important criterion in the selection of plantings consisted in the religious and folk symbolism, as well as aesthetic values and frost resistance of the chosen plants. The plan assumes planting uniform, compact groups of plants that obtain the best decorative effects in bulk, during seasonal flowering. They will become a kind of stage design for the celebrated liturgy. They must therefore foster an atmosphere of prayer and contemplation. This vegetation is to supplement and enrich the existing tree stand. In close proximity to the orthodox church, evergreen boxwood (Buxus sempervirens S.) was introduced, along with roses (Rosa) of 'Nostalgia' variety, and panicles hydrangea (Hydrangea paniculata) of 'Little Lime' variety. Along the fences, parallel to the longer sides of the orthodox church, a low hedge of cut boxwood has been planned. It has been decided that plantings should be introduced of sculpted hedgerows in order to emphasize the compositional layout and the aesthetic frame of the building. In the outside part of the surround, it is proposed that larger spherical forms are introduced, creating a rhythm. In the interior of a rectangular boxwood quarter, plantings of white and red roses are planned, along with white hydrangeas and lilacs (Syringa meyeri) of 'Palibin' variety. Due to the fact that as many as 8 trees are scheduled to be cut down, it is also proposed that two red maples or beeches be planted (they will constitute an accent of prominent elements, well visible from the valley after the embankment has been reclaimed and developed) as well as 12 pieces of a small, spherical lime tree variety called the 'Silver Globe'. Behind the four tombstones, we have planned the trimmed, rectangular forms of hornbeam, and beneath them, flower beds of the Funkia (Hosta) of 'Krossa Regal' variety, the ostrich fern (Matteuccia struthiopteris) of "The King" variety, and perwinkle (Vinca) of the 'Ralph Shugert' variety. The use of one-colour crocus groups is proposed in lawn turf. 
The presented concept of the garden meets the needs of its contemporary users: the clergy, the congregation, and the tourists. Plant species proposed for planting create a composition that will emphasize the seriousness of the place, as well as being adapted to the habitat conditions (tree stand, projection) and compatible with the landscape. The plant material was chosen so as not to obscure the temple, but instead to create order and harmony (Figures 6 and 7).

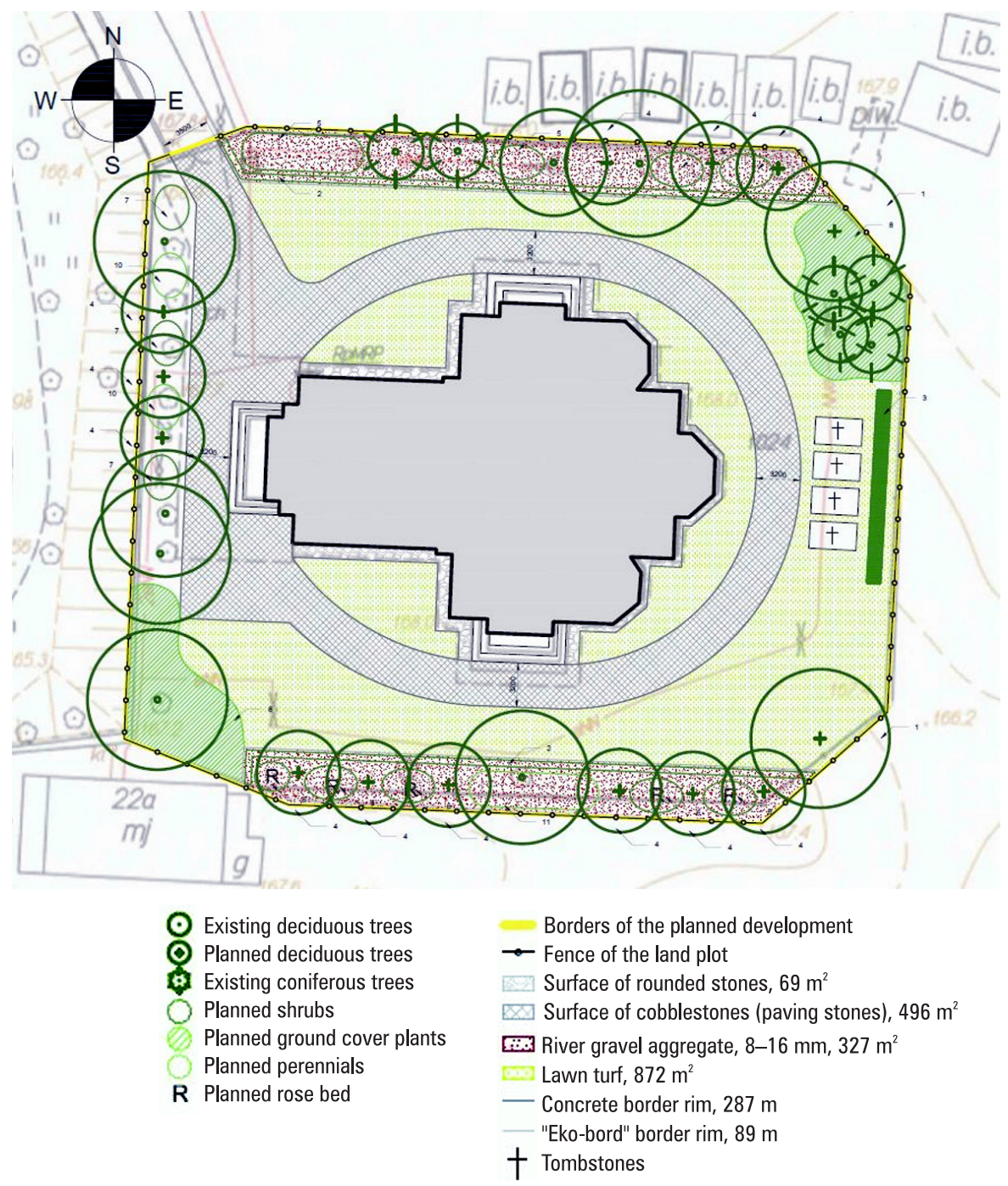

Source: developed by the author, 2017

Fig. 6. Concept plan for the greenery around the orthodox church in Włodawa - view from the top 


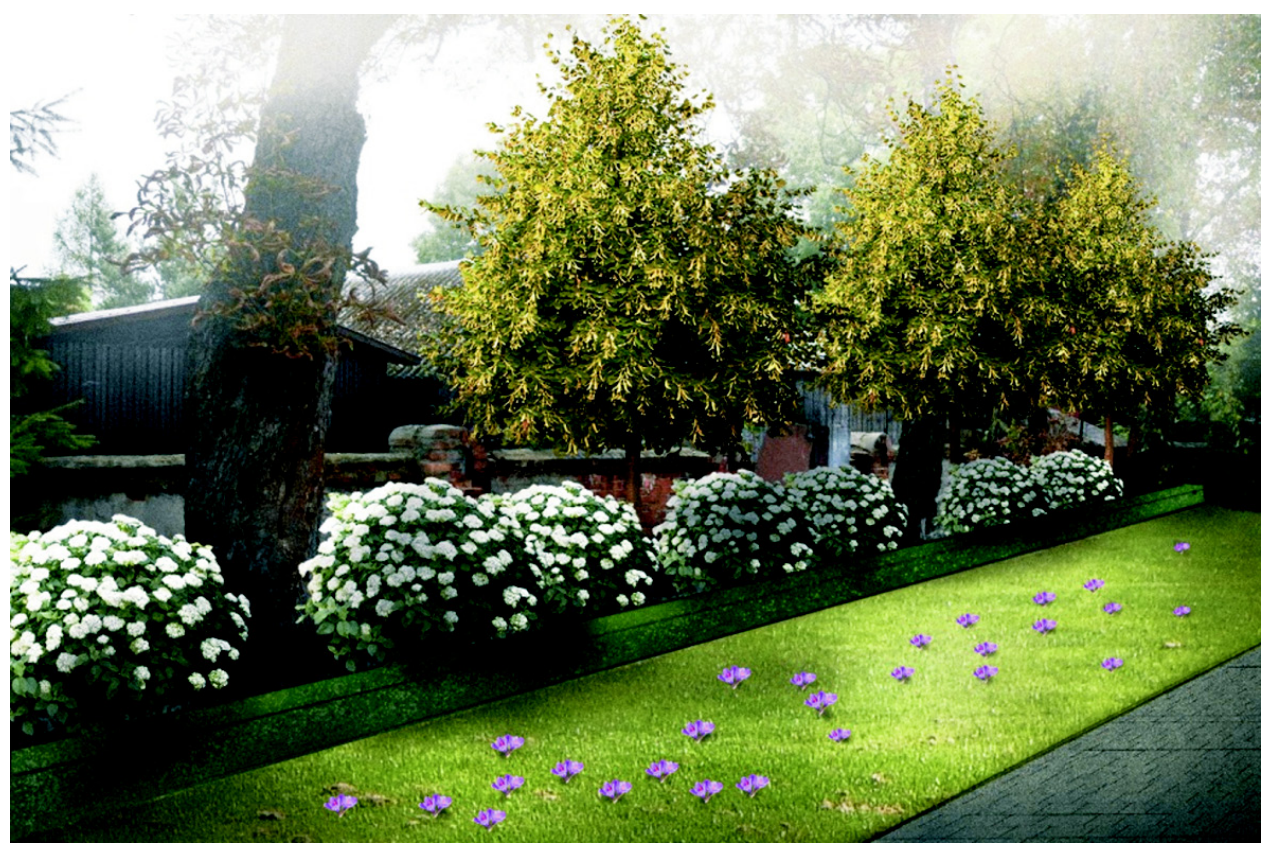

Source: developed by the author, 2017

Fig. 7. Concept plan for the greenery around the orthodox church in Włodawa - computer rendering

\section{Conclusions}

The main assumed goal of the present work was to investigate the effectiveness of the use and the potential of ultrasound computed tomography in the restoration of a sacred object. The need for such research springs from the demand on the part of the Polish milieu of monument conservators and architects for new methods and tools supporting the shaping and development of space. The research confirmed the legitimacy of the selected method, and the correct selection of tools suitable for studying cultural heritage and regional architecture. The collected data became the foundation for the information on the tree stand resources, and went on to serve as the basis for the development of the design of the church's surroundings.

\section{References}

Brazee N.J., Marra R., Göcke L., Van Wassenaer P. 2011. Non-destructive assessment of internal decay in three hardwood species of northeastern North America Rusing sonic and electrical impedance tomography. Forestry, 84(1), 33-39.

Chomicz E. 2007. Bezinwazyjne metody wykrywania defektów wewnątrz pni drzew stojących (Tomograf PiCUS Sonic i PiCUS ${ }^{\circ}$ Treetronic). Leśne Prace Bad., 3, 117-121. 
Chomicz E. 2010. Bezinwazyjne diagnozowanie kondycji drzew zabytkowych z zastosowaniem tomografów PiCUS*. Kurier Konserwatorski, 8, 29-32.

Durlak W., Dudkiewicz M., Pudelska K., Dąbski M. 2017a. Diagnozowanie kondycji drzew z wykorzystaniem tomografii komputerowej. Acta Sci. Pol., Formatio Circumiectus, 2, 71-83.

Durlak W., Dudkiewicz M., Szmagara M., Żuraw B. 2017b. Zastosowanie PiCUS` Sonic Tomograph 3 w badaniach dendroflory zespołu zamkowo-dworskiego w Krupem gm. Krasnystaw. Annales Horticulturae, XXVII (4), 19-32.

Göcke L., Rust S., Weihs U., Günther T., Rücker C. 2007. Combining Sonic and Electrical Impedance Tomography for the Nondestructive Testing of Trees. Proceedings of the 15th International Symposium on Nondestructive Testing of Wood, September 10-12. 2007, Duluth, Minnesota, USA, 31-42.

Hayes E. 2002. Tree Risk Assessment \& Tree Mechanics. Arborist News, 6 (11), 33-39.

Kane B., Ryan D., Bloniarz D.V. 2001. Comparing formula that assess strength lossdue to decay in trees. J. Arboricul., 27(2), 78-87.

Keczyńscy E. i A. 1999. Drewniane cerkwie białostocczyzny. Związek Białoruski w RP, Białystok - Białowieża.

Kępkowicz A., Gawryluk A. 2009. Zieleń w otoczeniu współczesnej cerkwi, koncepcja projektowa w Bielsku Podlaskim, 1, 54-58.

Kujawska M., Łuczaj Ł. 2016. Rośliny w wierzeniach i zwyczajach ludowych. Polskie Towarzystwo Ludoznawcze, Wrocław.

Luley C.L. 2005. Wood decay fungi common to living urban trees in the northeast and central United States. Urban Forestry LLC, Naples, NY, 61.

Mattheck C., Bethge K., Weber K. 2015. The body language of trees. Encyclopedia of Visual Tree Assessment. Karlsruhe Institute of Technology - Campus North. Karlsruhe Germany, 404-405.

Misiak T. 2010. Magiczne drzewa w dziejach, legendach i środowisku nad środkowym Sanem. Podkarpacki Instytut Książki i Marketingu, Rzeszów.

Mydłowska A. 2014. Ochrona zieleni w procesie inwestycyjnym z uwzględnieniem wiedzy dendrologicznej. Załącznik do materiałów szkoleniowych „Wizualna diagnoza drzew zagrażających bezpieczeństwu - metody i sposoby usprawniające kontrolę drzewostanu miejskiego", 20-21 listopada. Dendros, Poznań.

Pelica G.J. 2015. Dzieje parafii Narodzenia Bogarodzicy we Włodawie, http://cerkiew.wlodawa. pl/historia.htm (accessed: 1.06.2017).

Pokorny J. 2006. Urban Tree Risk Management: A Community Guide to Program Design and Implementation. NA-TP-03-03.

Seneta W., Dolatowski J. 2012. Dendrologia. Wydawnictwo Naukowe PWN, Warszawa.

Suchocka M. 2012. Zalety i ograniczenia stosowania wizualnej metody oceny drzew (VTA) jako odpowiedź na problemy związane z zagrożeniami powodowanymi przez drzewa miejskie. Człowiek i Środowisko, 36 (1-2), 97-110.

Superczyńska P. 2002. Parafia prawosławna we Włodawie [in:] Włodawa. Miasto i region na przełomie XX/XXI wieku, ed. E. Olszewski. Towarzystwo Przyjaciół Ziemi Włodawskiej, Lublin-Włodawa, 270-271.

Szary A. 2015. Bieszczadzkie motywy roślinne. Między światem żywych a krainą umarłych. Wyd. Carpathia, Rzeszów.

Szczepanowska H., Olizar J., Borowski J., Sitarski M., Suchocka M., Szadkowska E. 2010. Synteza pracy „Opracowanie nowej metody określania wartości drzew wraz ze współczynnikami różnicującymi oraz merytorycznym uzasadnieniem metody i zasadnością jej wprowadzenia do obiegu prawnego". IGPiM, Warszawa. 
Szcześniak K. 2013. Świat roślin światem ludzi. Na pograniczu wschodniej i zachodniej Słowiańszczyzny. Wyd. UG, Gdańsk.

Uścinowicz J. 1997. Symbol, archetyp, struktura, hermeneutyka tradycji w architekturze świątyni ortodoksyjnej. Politechnika Białostocka, Białystok.

Wang X., Allison R.B. 2008. Decay detection in red oak trees using a combination of visual inspection, acoustic testing, and resistance microdrilling. Arboriculture \& Urban Forestry, $34(1), 1-4$.

Dr inż. arch. kraj. Margot Dudkiewicz

Katedra Roślin Ozdobnych, Dendrologii i Architektury Krajobrazu

Wydział Ogrodnictwa i Architektury Krajobrazu

Uniwersytet Przyrodniczy w Lublinie

ul. Głęboka 28, 20-612 Lublin

e-mail: margotdudkiewicz@o2.pl 